\title{
Spontaneous rupture of hepatic metastasis from small cell neuroendocrine carcinoma of maxillary sinus
}

Yun-fei Duan', Yan Tan², Bo Yuan³ and Feng Zhu' ${ }^{1 *}$

\begin{abstract}
Background: Small cell neuroendocrine carcinoma of the maxillary sinus, a rare malignant tumor, has a poor prognosis because of its high incidence of metastasis. Moreover, metastatic cancer-induced hepatic rupture, characterized by hemoperitoneum, is infrequent, although several lines of evidences have reported that a wide variety of other neoplasms can cause this usually fatal manifestation.

Case presentation: We now present the first case of a 49-year-old man with spontaneous rupture of hepatic metastasis from small cell neuroendocrine carcinoma of the maxillary sinus and ultimately resulted in massive intraperitoneal bleeding, which was successfully controlled by subsequent surgery (partial hepatectomy). The postoperative clinical manifestation of the patient was uneventful. He was discharged on the 16th day after operation and without any complication.

Conclusions: Small cell neuroendocrine carcinoma of the maxillary sinus is very scarce and unfortunately has a poor prognosis. It has potential to cause spontaneous metastatic rupture which can elicit fatal hemorrhage. Emergency surgery is effective, although the long-term outcome is still unsatisfactory.
\end{abstract}

Keywords: Maxillary sinus, Small cell neuroendocrine carcinoma, Hepatic metastases, Hemoperitoneum, Hepatectomy

\section{Background}

Small cell neuroendocrine carcinoma of maxillary sinus is a rare and aggressive malignant disease. Non-traumatic rupture of the liver frequently occurred in primary benign or malignant tumors, metastatic carcinoma, peliosishepatis, polyarteritisnodosa, systemic lupus erythematosus, and toxemia of pregnancy [1]. However, spontaneous hepatic rupture induced by metastatic cancer, which presented as hemoperitoneum, is not common [2]. We currently reported a patient with hemoperitoneum due to bleeding hepatic metastasis which was originated from small cell neuroendocrine carcinoma of the maxillary sinus, although there is no literature reporting it.

\section{Case presentation}

A 49-year-old man had undergone surgery to resect a small cell neuroendocrine carcinoma (SNEC) of the right

\footnotetext{
*Correspondence: dahe1971@163.com

'Department of Hepatobiliary Surgery, The Third Affiliated Hospital of Soochow University, 185 Juqian Street, Changzhou, Jiangsu 213003, China Full list of author information is available at the end of the article
}

upper maxillary sinus 21 months previously (Figure 1). He underwent preoperative 'pingyangmycin'10 days of chemotherapy. The patient complained about persistent and severe right upper quadrant pain which lasted about 6 hours.

We observed that he had a pale complexion and distended, tender abdomen after careful physical examinations. The vital signs were a temperature of $36.8^{\circ} \mathrm{C}$, blood pressure of $90 / 55 \mathrm{mmHg}$, and pulse rate of $130 / \mathrm{min}$.

The hematological data were as follows: white blood cell (WBC) count $12.4 \times 10^{3} / \mathrm{mL}\left(3.5 \times 10^{3} / \mathrm{mL}-9.5 \times 10^{3} / \mathrm{mL}\right)$, hemoglobin $80 \mathrm{~g} / \mathrm{L}(130-175 \mathrm{~g} / \mathrm{L})$, hematocrit 0.233 (0.4$0.5)$, platelets $161 \times 10^{3} / \mathrm{mL}\left(125 \times 10^{3} / \mathrm{mL}-350 \times 10^{3} / \mathrm{mL}\right)$, and prothrombin time (PT) $13.3 \mathrm{~s}(9-13 \mathrm{~s})$. The hepatic function data were as follows: alanine aminotransferase (ALT) $98 \mathrm{U} / \mathrm{L}(9-50 \mathrm{U} / \mathrm{L})$, aspartate transaminase (AST) $15 \mathrm{U} / \mathrm{L}$ (15-40U/L), $\gamma$-glutamyltranspeptidase $(\gamma$-GTP) $164 \mathrm{U} / \mathrm{L}(10-60 \mathrm{U} / \mathrm{L})$, total protein $56.6 \mathrm{~g} / \mathrm{L}(60-82 \mathrm{~g} / \mathrm{L})$, and total bilirubin $9.6 \mu \mathrm{mol} / \mathrm{L}(4-19 \mu \mathrm{mol} / \mathrm{L})$. Markers for hepatitis viruses except for hepatitis B surface antibody

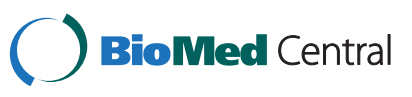



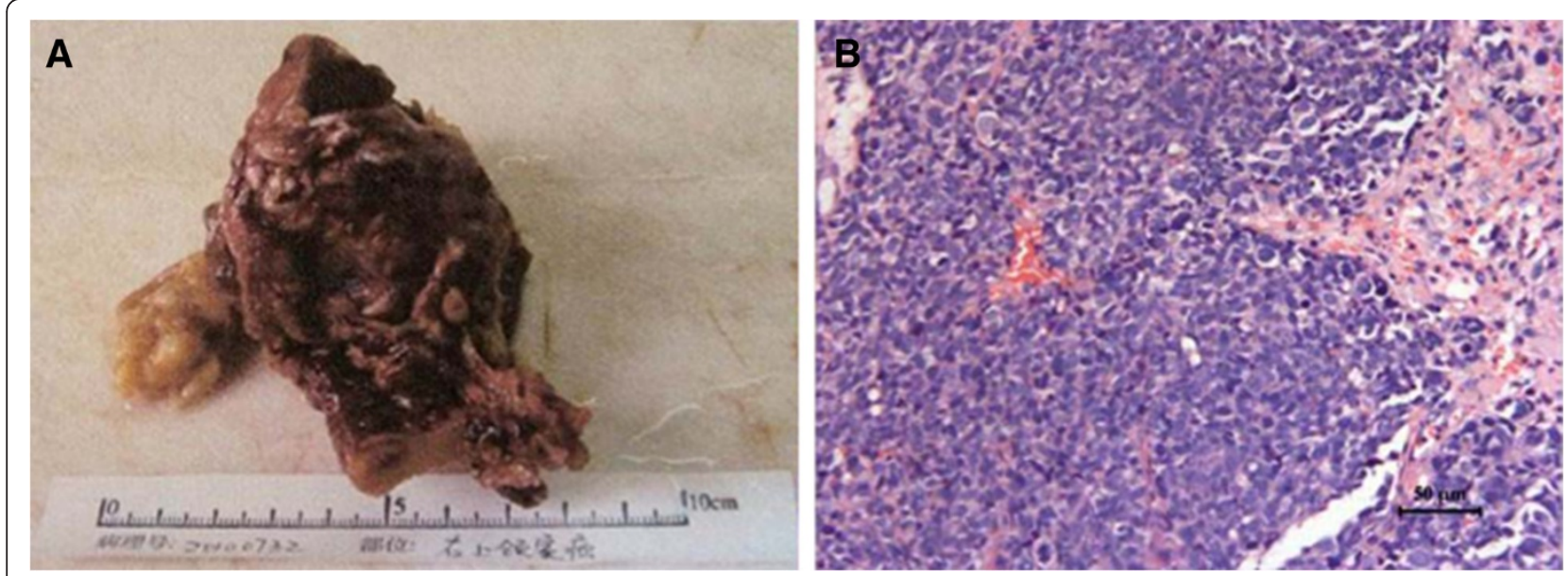

Figure 1 The specimen of the maxillary sinus carcinoma (A) and it's HE staining (B). The tumors are composed of small-sized regular cells which are arranged in broad sheets, nests, and cords.

were all negative. As to tumor markers, serum levels of carcino-embryonalantigen (CEA) were slightly increased. Additionally, serum levels of carbohydrate-antigen 19-9 (CA19-9), neurone-specific enolase (NSE), alpha-fetoprotein (AFP), cytokeratin 19 fragment (CY211), carbohydrateantigen 125 (CA125), carbohydrate-antigen 724 (CA724), prostate-specific antigen (PSA), and squamous cell carcinoma (SCC) were totally at normal levels (Table 1). Abdominal ultrasonography showed that isolated lesion corresponded to blood on diagnostic puncture in the liver and ascites. Computed tomography (CT) scan showed a large tumor in the right lobe of the liver and with an adjacent intraperitoneal hyperdense fluid collection (Figure 2). Besides, there was no underlying cirrhosis. Furthermore, CT scan revealed no abnormity in both lungs. We considered that the tumor was resectable which was based on the results of CT scan and liver function.

After fast-track resuscitation (4 units of packed red blood cells $(600 \mathrm{~mL})$ and 1,000 $\mathrm{mL}$ hetastarch 130/0.4 hydroxyethyl starch), the hemodynamics of the patient

Table 1 Tumor markers of the patient

\begin{tabular}{lll}
\hline Parameter & Patient & Normal range \\
\hline CEA $(\mathrm{ng} / \mathrm{mL})$ & 6.77 & $0.00-5.00$ \\
CA19-9 $(\mathrm{U} / \mathrm{mL})$ & 21.71 & $0.00-37.00$ \\
AFP $(\mathrm{ng} / \mathrm{mL})$ & 3.04 & $0.00-8.00$ \\
NSE $(\mathrm{ng} / \mathrm{mL})$ & 0.9 & $0.00-16.30$ \\
CA125 $(\mathrm{U} / \mathrm{mL})$ & 9.60 & $0.00-35.00$ \\
CA724 $(U / \mathrm{mL})$ & 0.2 & $0.00-6.90$ \\
CY211 $(\mathrm{ng} / \mathrm{mL})$ & 3.16 & $0.10-3.30$ \\
PSA $(\mathrm{ng} / \mathrm{mL})$ & 0.56 & $0.00-4.00$ \\
SCC $(\mathrm{ng} / \mathrm{mL})$ & 0.1 & $0.00-1.50$ \\
\hline
\end{tabular}

became relatively stable. Moreover, 2,500 $\mathrm{mL}$ of blood with clots were observed in the abdominal cavity in the operation. The liver tissue of the patient showed a normal color and a smooth surface in appearance, but there was an isolated lesion in segment 6 with a $6 \mathrm{~cm}$ laceration of the capsule, which skeptically was malignant tumor from macroscopical observation. There were no other observed bleeding sites. A resection of segment 6 of the liver was performed.

The resected tumor was $8 \times 7 \times 6.5 \mathrm{~cm}$ in size. The immunohistochemisty findings were as follows: Hepatocyte (-), CK5/6 (-), CK34 (-), P63 (-), CK8/18 (+), Vimentin (-), CK35 (+), Ki-67 proliferation index was more than 70\% (+). Combined with the observation of HE staining (Figure 3), microscopic examination of the tumor confirmed a metastatic poorly differentiated carcinoma. Repeated immuno-

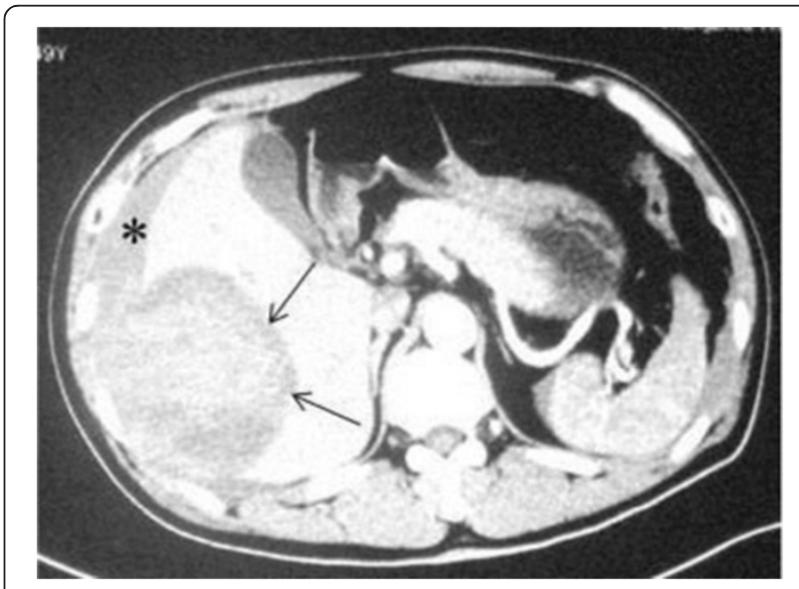

Figure 2 CT reveals a large tumor (arrows) in the right lobe of the liver along with an adjacent intraperitoneal hyperdense fluid collection (black asterisk). 


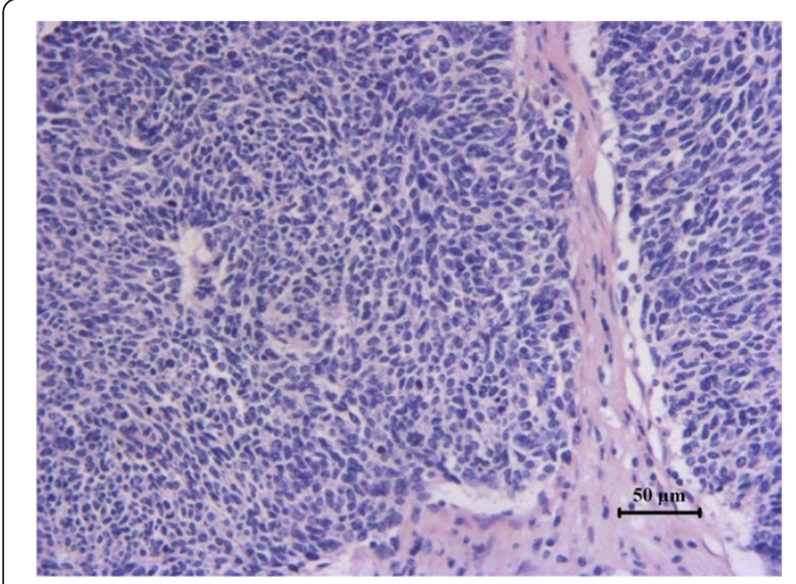

Figure 3 The hepatic tumors are composed of small-sized regular cells which are arranged in broad sheets, nests, and cords. Many of the cells contain cribriform nuclei with a fine reticular chromatin pattern and small amounts of cytoplasm.

histochemistry for tissues of carcinoma of maxillary sinus and metastatic hepatic carcinoma showed that Hepatocyte $(-), \operatorname{CgA}(-), \operatorname{CD} 56(+), \operatorname{Syn}(+)$ (Figure 4). Ultimately, we diagnosed and defined as hepatic metastases from small cell neuroendocrine carcinoma of maxillary sinus.

The patient was discharged on the 16th day after surgery and without any complication. He declined chemotherapy and died of cachexia and pulmonary metastasis after 7 months without the incidence of recurrent hemoperitoneum.

\section{Discussion}

Small cell neuroendocrine carcinoma of the sinonasal region is not common of the sinonasal carcinomas with neuroendocrine differentiation [3]. The histogenesis of the neuroendocrine differentiated tumors is not clear. It has been postulated that, outside the lung, this tumor is derived from the neuroendocrine amine precursor uptake decarboxylase (APUD) cells, which are widely distributed in the body. The tumors are composed of small-sized regular cells which are arranged in broad sheets, nests, and cords. Many of the cells contain cribriform nuclei with a fine reticular chromatin pattern and small to moderate amounts of cytoplasm [4]. Immunohistochemical observation is essential to make a pathological diagnosis. SNEC has been reported to stain strongly with synaptophysin and CD56 nerve cell adhesion molecule and weakly with chromogranin A and CAM 5.2/AE-1 [5]. The prognosis in cases of head and neck SNEC is very poor because of its high metastatic rate [6]. In this patient we reported, the tumor metastasized to the liver 21 months after maxillectomy.

Metastatic disease of the liver resulting in spontaneous hepatic rupture is rare as compared with primary hepatic tumor $[2,7]$. This probably reflects the tendency of metastatic cancer to be less vascular and invasive, and to penetrate the liver capsule less frequently than primary tumor [7]. A recent study reviewed that there have some reported cases of spontaneous rupture of hepatic metastases from primary sites including the prostate, lung, esophagus, stomach, kidney, colon, pancreas, testicle, gallbladder, skin, choriocarcinoma, malignant melanoma, nasopharynx, and others [7-20]. But there was no report regarding rupture of hepatic metastases from SNEC of the maxillary sinus.

The typical presentation is sudden epigastric or right hypochondria pain. Shock could be observed in some patients, while most patients were manifested with peritonitis or abdominal distension. Some patients are paracentesis-positive with blood-stained ascites. Ultrasonography, a simple, quick, non-invasive investigating method, can locate the ruptured tumor and reveal a free intraperitoneal blood collection. CT scan is invaluable for diagnosis and treatment planning because it can check the severity of the cirrhosis and locate the tumor.

Rupture of a hepatic metastasis frequently results in massive hemoperitoneum, which may be a terminal event [21]. For these patients, it is therefore crucial to control the bleeding and restore the blood pressure as soon as possible. Transcatheter hepatic arterial embolization (TAE) may seem to be ideal for these patients, since it avoids general anesthesia to stop the bleeding without operation [22], but it also has some demerits, including recurrent bleeding and liver failure [22,23], peritoneal abscess [24], and implanted metastases [25,26]. Furthermore, long-term results are poor if it is used as a sole treatment approach [27], and it is not applicable when the main trunk of the portal vein is obstructed. In addition, a two-stage surgical operation (that is, TAE followed by liver resection) would inevitably increase the hospital stay and the cost. For our patients, one-stage hepatectomy is still a good treatment method for those who are stable hemodynamically and has a reasonable liver function as well as the lesion is peripherally located.

\section{Conclusions}

Small cell neuroendocrine carcinoma of the maxillary sinus is very rare and has a poor prognosis. It may cause spontaneous metastatic rupture which resulted in fatal hemorrhage. Emergency surgery is effective but the outcome is still unsatisfactory.

\section{Consent}

Written informed consent was obtained from the patient's son for publication of this report and any accompanying images. 

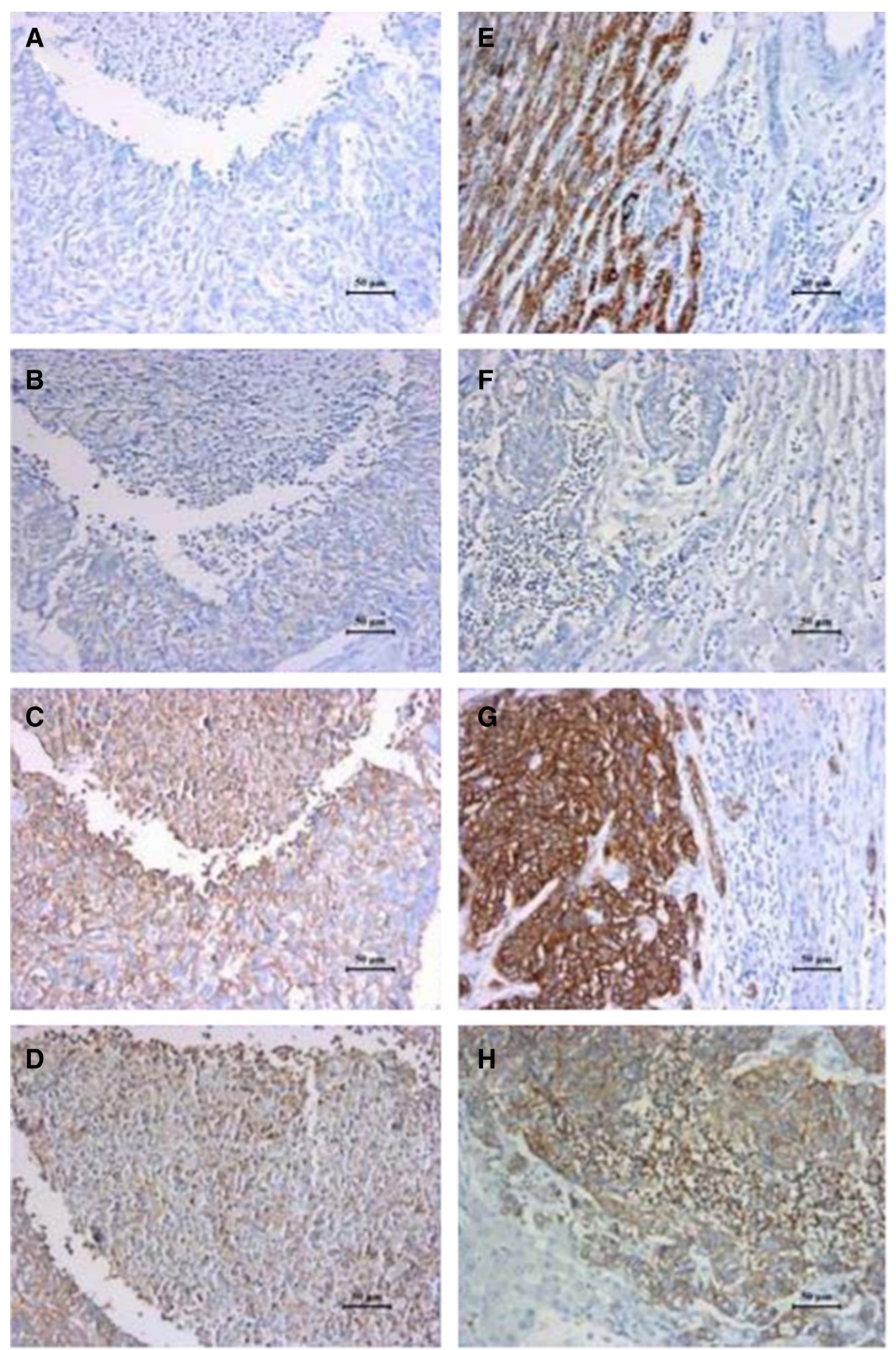

Figure 4 Maxillary sinus carcinoma and metastatic hepatic carcinoma stained negative for Hepatocyte $(A, E)$ and $\mathrm{CgA}(\mathrm{B}, \mathrm{F})$, while positive for CD56 (C,G) and Syn (D,H). 


\section{Competing interests}

The authors declare that they have no competing interests. No benefits in any form have been received or will be received from a commercial party related directly or indirectly to the subject of this article.

\section{Authors' contributions}

$\mathrm{Y}$-fD and FZ participated in the clinical management of the patient and wrote the manuscript. YT and BY carried out the pathological examination. Y-fD and

FZ were involved in the final editing. All authors approved the final manuscript.

\section{Acknowledgments}

The authors thank Dr. Chun Yang for his technical support.

\section{Author details}

${ }^{1}$ Department of Hepatobiliary Surgery, The Third Affiliated Hospital of Soochow University, 185 Juqian Street, Changzhou, Jiangsu 213003, China. ${ }^{2}$ Department of Pathology, The Third Affiliated Hospital of Soochow University, Changzhou 213003, China. ${ }^{3}$ Department of Hepatobiliary Surgery, Changzhou TCM Hospital, Changzhou 213003, China.

Received: 2 September 2013 Accepted: 20 April 2014 Published: 27 April 2014

\section{References}

1. Mittleman RE: Hepatic rupture due to metastatic lung carcinoma. Am J Clin Pathol 1987, 88:506-509.

2. Schoedel KE, Dekker A: Hemoperitoneum in the setting of metastatic cancer to the liver. A report of two cases with review of the literature. Dig Dis Sci 1992, 37:153-154.

3. Huang SF, Chuang WY, Cheng SD, Hsin L, Lee LY, Kao HK: A colliding maxillary sinus cancer of adenosquamous carcinoma and small cell neuroendocrine carcinoma-a case report with EGFR copy number analysis. World J Surg Oncol 2010, 8:92.

4. Rejowski JE, Campanella RS, Block LJ: Small cell carcinoma of the nose and paranasal sinuses. Otolaryngol Head Neck Surg 1982, 90:516-517.

5. Avitia S, Osborne RF: Blindness: a sequela of sinonasal small cell neuroendocrine carcinoma. Ear Nose Throat J 2004, 83:530-532.

6. Mineta H, Miura K, Takebayashi S, Araki K, Ueda Y, Harada H, Misawa K: Immunohistochemical analysis of small cell carcinoma of the head and neck: a report of four patients and a review of sixteen patients in the literature with ectopic hormone production. Ann Otol Rhinol Laryngol 2001, 110:76-82.

7. Tung CF, Chang CS, Chow WK, Peng YC, Hwang Jl, Wen MC: Hemoperitoneum secondary to spontaneous rupture of metastatic epidermoid carcinoma of liver: case report and review of the literature. Hepatogastroenterology 2002, 49:1415-1417.

8. Murakami R, Taniai N, Kumazaki T, Kobayashi Y, Ogura J, Ichikawa T: Rupture of a hepatic metastasis from renal cell carcinoma. Clin Imaging 2000, 24:72-74.

9. Dousei T, Miyata M, Yamaguchi T, Nagaoka M, Takahashi E, Kawashima Y: Rupture of liver metastasis of malignant melanoma-a case of hepatic resection. Jpn J Surg 1991, 21:480-484.

10. Preissler G, Graeb C, Steib C, Zech CJ, Weiler C, Stemmler HJ, Jauch KW, Gruener $\mathrm{NH}$ : Acute liver failure, rupture and hemorrhagic shock as primary manifestation of advanced metastatic disease. Anticancer Res 2012, 32:3449-3454.

11. Chun HJ, Osuga K, Fahrni M, Nakamura H: Massive bleeding of ruptured metastatic hepatic melanoma treated by transarterial embolization. Jpn J Radiol 2010, 28:395-397.

12. Sohda T, Hanano T, Miyamoto H, Kitano Y, Iwata K, Yokoyama M, Irie M, Takeyama Y, Shakado S, Sakisaka S: Spontaneous rupture of metastatic alpha-fetoprotein-producing gastric cancer of the liver. Hepatol Int 2008, 2:258-261.

13. Yoshida H, Mamada $Y$, Taniai $N$, Mizuguchi $Y$, Nakamura $Y$, Nomura $T$, Yoshioka M, Kiyama T, Kato S, Nishi K, Naito Z, Akimaru K, Tajiri T: Ruptured metastatic liver tumor from an alpha-fetoprotein-producing gastric cancer. J Nippon Med Sch 2005, 72:236-241.

14. Kadowaki T, Hamada H, Yokoyama A, Ito R, Ishimaru S, Ohnishi H, Katayama H, Oshima M, Okura T, Kito K, Higaki J: Hemoperitoneum secondary to spontaneous rupture of hepatic metastasis from lung cancer. Intern Med 2005, 44:290-293.
15. Sakai M, Oguri T, Sato S, Hattori N, Bessho Y, Achiwa H, Maeda H, Niimi T, Ueda R: Spontaneous hepatic rupture due to metastatic tumor of lung adenocarcinoma. Intern Med 2005, 44:50-54.

16. Takayama T, Kato H, Tachimori Y, Watanabe H, Furukawa H, Takayasu K, Sakamoto M, Makuuchi M: Treatment of rupture of a liver metastasis from esophageal leiomyosarcoma. Jpn J Clin Oncol 1996, 26:248-251.

17. Dewar GA, Griffin SM, Van Hasselt CA, Lam WY, Li AK: Fatal haemoperitoneum as a result of liver metastases from nasopharyngeal cancer. Eur J Surg Oncol 1991, 17:551-554.

18. Gulati A, Vyas S, Lal A, Harsha TS, Gupta V, Nijhawan R, Khandelwal N: Spontaneous rupture of hepatic metastasis from choriocarcinoma: a review of imaging and management. Ann Hepatol 2009, 8:384-387.

19. Pastor Navarro H, Donate Moreno MJ, Ruiz Mondejar R, Pastor Guzman JM Salinas Sanchez AS, Virseda Rodriguez JA: [Hemoperitoneum and death due to hepatoesplenic metastasis rupture in a testicular tumor]. Actas Urol Esp 2007, 31:1175-1178.

20. De Faria G: Cancer of the prostate and death caused by hemoperitoneum resulting from the rupture of metastatic nodule of the liver. Rev Bras Cir 1954, 27:35-48.

21. Lucey BC, Varghese JC, Anderson SW, Soto JA: Spontaneous hemoperitoneum: a bloody mess. Emerg Radiol 2007, 14:65-75.

22. Leung CS, Tang CN, Fung KH, Li MK: A retrospective review of transcatheter hepatic arterial embolisation for ruptured hepatocellular carcinoma. J R Coll Surg Edinb 2002, 47:685-688.

23. Tanaka A, Takeda R, Mukaihara S, Hayakawa K, Shibata T, Itoh K, Nishida N, Nakao K, Fukuda Y, Chiba T: Treatment of ruptured hepatocellular carcinoma. Int J Clin Oncol 2001, 6:291-295.

24. Yokoi Y, Suzuki S, Sakaguchi T, Okumura T, Kurachi K, Konno H, Nakamura S: Subphrenic abscess formation following superselective transcatheter chemoembolization for hepatocellular carcinoma. Radiat Med 2002, 20:45-49.

25. Sonoda T, Kanematsu T, Takenaka K, Sugimachi K: Ruptured hepatocellular carcinoma evokes risk of implanted metastases. J Surg Oncol 1989, 41:183-186

26. Yeh CN, Chen HM, Chen MF, Chao TC: Peritoneal implanted hepatocellula carcinoma with rupture after TACE presented as acute appendicitis. Hepatogastroenterology 2002, 49:938-940.

27. Zhu LX, Wang GS, Fan ST: Spontaneous rupture of hepatocellular carcinoma. Br J Surg 1996, 83:602-607.

doi:10.1186/1477-7819-12-126

Cite this article as: Duan et al:: Spontaneous rupture of hepatic metastasis from small cell neuroendocrine carcinoma of maxillary sinus. World Journal of Surgical Oncology 2014 12:126.

\section{Submit your next manuscript to BioMed Central and take full advantage of:}

- Convenient online submission

- Thorough peer review

- No space constraints or color figure charges

- Immediate publication on acceptance

- Inclusion in PubMed, CAS, Scopus and Google Scholar

- Research which is freely available for redistribution 